\title{
PERFIL DO ESTUDANTE DE DIREITO, UTILIZAÇÃO DE METODOLOGIAS ATIVAS E REESTRUTURAÇÃO PEDAGÓGICA DOS CURRÍCULOS ACADÊMICOS
}

\author{
Mônica Mota Tassigny ${ }^{1}$ \\ Isabelly Cysne Augusto Maia ${ }^{2}$
}

\begin{abstract}
Resumo
Na tentativa de tornar os currículos do curso de direito mais flexíveis, a Resolução n 09/2004 fixou os conteúdos mínimos e ampliou a duração do curso de direito. Observa-se, entretanto, que o instrumento legislativo supracitado não atingiu seu desiderato, afinal, tanto os defensores, quanto os críticos das reformas curriculares, chegam a uma conclusão comum: as previsões de reformas não resolveram o problema do ensino jurídico, uma vez que esse permanece distante da realidade. Nesse sentido, o presente artigo objetiva caracterizar e analisar o perfil do estudante de direito, os currículos acadêmicos e a sua adequabilidade à realidade, propondo uma alteração didático-pedagógica do ensino jurídico, por meio da utilização das metodologias ativas. Realizou-se pesquisa bibliográfica, documental e de campo. No tocante a pesquisa documental, analisou-se as matrizes curriculares dos cursos de direito no Ceará, elucidando a relevância atribuída às disciplinas propedêuticas, profissionalizantes e práticas. Ademais, aplicou-se na pesquisa de campo questionário, com abordagem quantitativa, objetivando traçar o perfil dos estudantes de direito, identificando os principais escopos profissionais e opiniões dos discentes sobre os métodos de ensino e organização curricular. O desenvolvimento da pesquisa de campo deu-se mediante a técnica de coleta de dados Surveye snowball. Após verificar a crescente necessidade de novas formas de aprendizagem por parte dos alunos em consequência do surgimento de tecnologias e complexização das relações humanas, chegou-se a conclusão de que, não obstante, a flexibilização da estrutura curricular, formalmente estabelecida por meio da Resolução n ${ }^{\circ}$ 09/2004, as matrizes acadêmicas encontram-se defasadas e são alvos de crítica pelos estudantes. Dessa forma, propõe-se, ad initio, uma mudança didático pedagógica do ensino, com a aplicação de metodologias ativas.
\end{abstract}

Palavras-chave: Estudante de Direito; Metodologias Ativas; Currículo Acadêmico.

\section{INTRODUÇÃO}

Conforme expõe Horácio Wanderley (1992, p. 88), grande parte dos autores que estudam a crise do ensino jurídico no Brasil privilegiam a matriz curricular. Esses estudiosos entendem que o problema educacional do direito está no elenco de disciplinas que compõem o curso e que tal dificuldade poderá ser solucionada com alterações legislativas e formais nos currículos acadêmicos.

\footnotetext{
${ }^{1}$ Professora Dra. Titular dos Programas de Pós-Graduação em Administração (PPGA) e Programa de Pós-Graduação em Direito (PPGD) da Universidade de Fortaleza (UNIFOR).E-mail: monicatass@unifor.com.

${ }^{2}$ Mestranda em Ordem Jurídica Constitucional pela Universidade Federal do Ceará. E-mail: isabellycysne@gmail.com
} 
A legislação que orienta contemporaneamente a estruturação dos currículos jurídicos é a Portaria nº 09/2004 do CNE/CSE. Tal Portaria deu continuidade à indicação de um currículo acadêmico mínimo a ser ofertado pelas instituições de ensino, revelando-se, portanto, como um desenvolvimento da Resolução n 3/72 e da Portaria nº 1886/94.

Em consonância com a crítica traçada pelo autor supracitado (RODRIGUES, 1992, p. 96), as alterações curriculares idealizadas pelo legislador não foram adequadamente recepcionadas pelas instituições de ensino, uma vez que o currículo mínimo passou a ser utilizado como currículo pleno, deixando de acrescentar outras matérias que empreenderiam a adequação do curso às realidades regionais.

Assim, analisando-se a evolução das alterações curriculares realizadas pelo Estado, percebe-se que nenhuma delas deu fim a crise do ensino jurídico, o que nos conduz a duas hipóteses: "ou as reformas efetuadas até hoje não foram adequadas aos problemas apresentados, ou a questão do ensino do direito no país não se resume a questões curriculares". (RODRIGUES, 1992, p. 98).

Diante de tal cenário questiona-se: Após a integralização da matriz curricular, os graduandos sentem-se preparados para assumir o mercado de trabalho e atingirem seus objetivos profissionais? Uma proposta de alteração legislativa dos currículos acadêmicos é suficiente para a transformação do ensino jurídico, tornando-o mais crítico e próximo da realidade?

Desse modo, este artigo visa caracterizar e analisar o perfil do estudante de Direito, os currículos acadêmicos e adequabilidade desses à realidade, ou seja, o objetivo é refletir sobre a adequabilidade das matrizes curriculares e das metodologias utilizadas em sala de aula para que os graduandos tenham suas finalidades profissionais alcançadas, avaliando a qualidade do ensino jurídico.

A pesquisa desenvolveu-se por meio da pesquisa bibliográfica, documental e de campo, com abordagem quantitativa e qualitativa. Ad initio, realizou-se pesquisa bibliográfica, a fim de compreender as evoluções da legislação que regulamenta os currículos acadêmicos do curso de Direito.

A pesquisa documental, por sua vez, ocorreu mediante a análise quantitativa das ementas e currículos acadêmicos do curso de direito nas faculdades e universidades no Estado do Ceará, a fim de identificar a relevância atribuída às disciplinas propedêuticas, profissionalizantes e práticas, avaliando o percentual ocupado por cada uma das disciplinas no currículo acadêmico e se havia diferenças relevantes entre esses.

Na pesquisa de campo, foram registradas as opiniões de estudantes a partir do $5^{\circ}$ semestre. A referida pesquisa foi aplicada por meio de questionário da plataforma Google Docs, cujo link fora divulgado através de redes sociais, resultando na coleta de dados Surveye snowball. A coleta de dados Surveypode ser descrita como a obtenção de dados ou informações sobre características, ações ou opiniões sobre determinado grupo de pessoas, indicado como representante de uma população alvo, por meio de um instrumento de pesquisa, normalmente um 
questionário ((FREITAS et al., 2000). A técnica snowball, por sua vez, é utilizada em pesquisas sociais onde os participantes iniciais de um estudo indicam novos participantes que por sua vez indicam novos participantes e assim sucessivamente, até que seja alcançado o objetivo proposto. "O método de amostragem em bola de neve pressupõe que há uma ligação entre os membros da população dado pela característica de interesse, isto é, os membros da população são capazes de identificar outros membros da mesma”. (DEWES, 2013, p. 10).

Desta feita, para coletar-se as opiniões dos estudantes de direito e traçar seus perfis, aplicou-se um questionário de 10 perguntas, cujo objetivo estava em identificar, quantitativamente, a opinião dos estudantes sobre algumas práticas docentes e constituição de currículo acadêmico. A pesquisa foi aplicada com alunos a partir do $5^{\circ}$ semestre do curso de direito de faculdades e universidades públicas e privadas e atingiu uma amostra de 114 (cento e quatorze) discentes.

Este artigo está organizado do seguinte modo. Inicialmente é desenvolvida uma análise bibliográfica e documental das disciplinas propedêuticas, profissionalizantes, práticas e em média quantos por cento das matrizes curriculares são ocupados por cada um desses blocos, evidenciando-se a similaridade entre os currículos acadêmicos. Em seguida, fez-se uma análise das técnicas de metodologia ativa e da sua importância para o aperfeiçoamento do ensino jurídico, por fim, apresentaram-se os resultados obtidos com a pesquisa empírica, confrontando-os com o referencial teórico utilizado na confecção do artigo. A contribuição do presente trabalho está em sugerir uma alteração didático pedagógica nos cursos de direito e não apenas uma reformulação formal nos currículos.

\section{INSTRUMENTOS LEGISLATIVOS E AS MATRIZES CURRICULARES DOS CURSOS DE DIREITO NO ESTADO DO CEARÁ}

Os cursos jurídicos foram criados no Brasil mediante Lei de 11 de agosto de 1827, com sede em São Paulo e em Olinda. A essa época, os cursos jurídicos eram compostos por nove disciplinas e apresentavam duração de cinco anos.

Durante o período do império, em 1854, foram acrescidas as disciplinas de Direito Romano e de Direito Administrativo. Apenas em 1890, em razão da proclamação da República, a disciplina de Direito Eclesiástico deixou de ser obrigatória, implementando-se nos currículos acadêmicos as cadeiras de Filosofia e História do Direito e de Legislação comparada sobre o Direito Privado. No período republicano possibilitou-se, também, a criação das faculdades livres, encerrando-se o dualismo existente entre as faculdades de Direito de São Paulo e Recife.

Em 1931, a reforma Francisco Campos buscou conferir ao curso de Direito um caráter mais profissionalizante, dividindo-o em Bacharelado e Doutorado. Os estudantes do curso de Direito Bacharelado 
teriam uma visão mais prática, ao passo que os alunos do curso de Direito na modalidade Doutorado seriam preparados para a vida acadêmica. Essa alteração, entretanto, não produziu os resultados esperados, uma vez que o curso de bacharelado permaneceu no mesmo nível e o de doutorado também não gerou os frutos pretendidos.

Em 1962, pela primeira vez, editou-se um currículo acadêmico mínimo, até então todos os currículos eram plenos. A duração do curso permaneceu em 5 (cinco) anos e o currículo mínimo era composto por 14 disciplinas, sendo todas de caráter profissionalizante, com exceção da disciplina de Introdução ao Ensino do Direito.

A Resolução n 3/72 reestruturou o currículo mínimo idealizado em 1962 e estabeleceu três disciplinas básicas, também chamadas de propedêuticas, quais sejam: Introdução ao Estudo do Direito, Economia e Sociologia. As demais disciplinas seriam profissionalizantes e pela primeira vez o currículo mínimo contemplou a prática do estagio supervisionado. A duração do curso de direito seria de 2.700 horas aula e poderia ser concluído em no mínimo quatro e no máximo sete anos letivos.

Os currículos implantados a partir da Resolução n³/72 demonstram o enfoque técnico atribuído aos cursos jurídicos, com o saber compartimentado e sem as devidas discussões epistemológicas e críticas de conteúdo. Não obstante a Resolução n ${ }^{\circ} 3 / 74$ tenha conferido maior autonomia às universidades, uma vez que estabelece apenas um currículo mínimo, percebesse que as instituições de ensino superior, na verdade, transformaram os currículos mínimos em currículos plenos, não efetivando a especificação dos currículos conforme a realidade social. (RODRIGUES, 1992, p. 96)

A resolução n³ 3/72 foi revogada e substituída pela Portaria n 1886/94. Dentre as inovações trazidas cita-se:

A integralização do estágio de prática jurídica como componente curricular, a ser desenvolvida de forma simulada ou real, com supervisão e orientação do Núcleo de Prática Jurídica da Instituição. Ainda a obrigatoriedade das disciplinas de Filosofia Geral e Jurídica, Ética Geral e Jurídica, Sociologia Geral e Jurídica, Economia e Ciência Política com caráter formativo. Também tornou obrigatória a produção e defesa da monografia no final do curso. (...) A Portaria nº 1886/94 determinava que os cursos jurídicos devessem contemplar o ensino, a pesquisa e a extensão de forma interligada e obrigatória. (ROCHA; ALVES; MUJAHED, 2016, p. 321)

Atualmente, o ensino do Direito no Brasil assenta-se na Resolução no 09/2004. Tal instrumento legislativo preocupa-se em inserir uma formação geral integrada numa perspectiva humanística, sem perder de vista o caráter crítico, promovendo uma intima interação entre o Eixo de formação Fundamental, Eixo de Formação Profissional e o Eixo de Formação Prática, conforme disposto no artigo $5^{\circ 3}$.

\footnotetext{
${ }^{3}$ Art. $5^{\circ} \mathrm{O}$ curso de graduação em Direito deverá contemplar, em seu Projeto Pedagógico e em sua Organização Curricular, conteúdos e atividades que atendam aos seguintes eixos interligados de formação: I - Eixo de Formação Fundamental, tem por objetivo integrar o estudante no campo, estabelecendo as relações do Direito com outras áreas do saber, abrangendo dentre outros, estudos que envolvam conteúdos essenciais sobre Antropologia, Ciência Política, Economia, Ética, Filosofia, História, Psicologia e Sociologia. II - Eixo de Formação Profissional, abrangendo, além do enfoque dogmático, o conhecimento e a aplicação, observadas
} 
A Resolução n 09/2004 estabelece o seguinte eixo curricular pra o curso de Direito:

Tabela 4 - Exos Curriculares para os cursos de Direito - Resolução n $09 / 2004$

Eixo Fundamental

Antropologia
Ciência Política
Economia

Ética

Filosofia

História

Psicologia

Sociologia
Eixo Profissional

Eixo Prático
Estágio Curricular

Supervisionado

Trabalho de Curso

Atividades

Complementares

\title{
Direito Processual Civil \\ Direito Econômico \\ Direito Penal \\ Direito do Trabalho \\ Direito Comercial \\ Direito Internacional \\ Fonte: Dias, 2014.
}

Dessa forma, realizou-se, inicialmente, uma análise dos currículos acadêmicos das faculdades e universidades de Direito no Estado do Ceará, comparando-os e avaliando o peso que as disciplinas do eixo fundamental (Propedêuticas), eixo profissional e do eixo prático ocupam em cada um deles.

\section{Eixo Fundamental: Disciplinas propedêuticas}

As chamadas disciplinas propedêuticas são de fundamental importância para a formação do Bacharel em Direito. Essas disciplinas contribuem para a formação de um profissional jurídico mais humano, crítico e reflexivo. De acordo com José Bittencourt Filho e Eneá de Stutz e Almeida (2003, p. 6283):

\begin{abstract}
A reflexão sobre temáticas sociais e educacionais, comumente reservada aos docentes das áreas de Sociologia, Filosofia, Pedagogia e afins, deve ser parte integrante do contexto das demais áreas e disciplinas, a fim de que as transformações presentes no universo do conhecimento não permaneçam confinadas a alguns domínios acadêmicos, mas sejam manejadas pelo maior número possível de docentes e protagonistas da educação. As condições para que tal intento possa ser levado a efeito, devem ser construídas e implantadas por meio de um processo de produção de consenso democrático nas IES, passando pelo
\end{abstract}

as peculiaridades dos diversos ramos do Direito, de qualquer natureza, estudados sistematicamente e contextualizados segundo a evolução da Ciência do Direito e sua aplicação às mudanças sociais, econômicas, políticas e culturais do Brasil e suas relações internacionais, incluindo-se necessariamente, dentre outros condizentes com o projeto pedagógico, conteúdos essenciais sobre Direito Constitucional, Direito Administrativo, Direito Tributário, Direito Penal, Direito Civil, Direito Empresarial, Direito do Trabalho, Direito Internacional e Direito Processual; e III - Eixo de Formação Prática, objetiva a integração entre a prática e os conteúdos teóricos desenvolvidos nos demais Eixos, especialmente nas atividades relacionadas com o Estágio Curricular Supervisionado, Trabalho de Curso e Atividades Complementares. 
compromisso ético-político com a informação qualificada com respeito às questões de relevo na formação dos discentes e no compromisso institucional com a contemporaneidade e a honestidade intelectual.

A interdisciplinaridade, tão importante para uma formação jurídica adequada e completa, só é alcançada com a promoção das disciplinas propedêuticas. Essas disciplinas, entretanto, são muitas vezes menosprezadas pelos discentes, sobretudo aqueles que se encontram no início do curso, por se entender que seu estudo deve ser logo superado para alcançar a imersão nas matérias efetivamente "de direito", as chamadas disciplinas profissionalizantes.

Antônio Alberto Machado (2009, p. 100) explica que esse enfoque demasiado nas disciplinas profissionalizantes em detrimento das disciplinas propedêuticas pode ser explicado pelo caráter tecnicista que os cursos de direito assumiram desde a década de 1930. Desde esse período, a razão cientifica ganhou maior importância em relação à autonomia crítica do bacharel, de modo que um estudo analítico e descritivo acerca do funcionamento das instituições ganhou uma maior importância que uma análise reflexiva.

Para a elaboração do presente estudo analisamos a matriz curricular de Universidades e Faculdades Públicas e Privadas, localizadas no Estado do Ceará. As disciplinas propedêuticas ocupam média de 10\% (dez por cento) do currículo dos cursos analisados, ou seja, as Instituições de Ensino Superior (IES) limitam-se a ofertar as disciplinas dispostas no Eixo Fundamental da Resolução n 09/2004, não obstante no inciso I do Artigo $5^{\circ}$ esteja expresso que o objetivo do Eixo Fundamental é empreender a relação do Direito com outras áreas do saber, abrangendo dentre outros, estudos que envolvam conteúdos essenciais de Antropologia, Ciência política, Economia, dentre outras, ou seja, as diretrizes curriculares impõem apenas o mínimo que deve ser ofertado pelas instituições de ensino.

Conforme expõe Horácio Wanderley (1992, p. 96), o que deveriam entender os responsáveis pelo curso de Direito é que o currículo mínimo é um currículo necessário, mas não um currículo suficiente, daí porque deve apresentar uma parte complementar e opcional. $\mathrm{Na}$ análise empreendida constata-se que dentre as disciplinas optativas ofertadas pelas IES dificilmente são disponibilizadas disciplinas de cunho filosófico e epistemológico, em regra, as disciplinas profissionalizantes também dominam as matrizes optativas.

Paviani e Pozenato (1980, p. 43) advertem sobre as consequências nefastas de um ensino jurídico tecnicista e meramente profissionalizante, em que as disciplinas propedêuticas são tidas como de somenos importância:

Um erro comum a muitos que frequentam cursos universitários é o de pretender que a Universidade deva se preocupar exclusivamente com a habilitação profissional. Assim o candidato ao magistério quer aprender aquilo que vai utilizar na profissão futura, o candidato à administração quer conhecer as técnicas de administração que lhe são úteis, e assim por diante. Ocorre, porém, que em qualquer profissão há o perigo da cristalização. Um engenheiro altamente capacitado para o momento presente, se não souber progredir será amanhã um profissional defasado. Mais do que o treinamento profissional, é sobretudo a 
atitude investigadora o elemento mais importante do ensino superior. Na Universidade o aluno deverá aprender a investigar, saber qual é o significado e quais são as exigências da investigação para que possa, com esse impulso inicial, permanecer numa atitude de progresso científico.

O fato é que os currículos tradicionais, em que as disciplinas propedêuticas têm sua importância minimizada, com carga horária reduzidíssima, devem ser superados, a fim de que a educação jurídica, a qual está notadamente em crise, torne-se menos tecnicista e dogmática e assuma caráter mais reflexivo e crítico. Tal objetivo, entretanto, só será atingido com a reformulação da matriz curricular, atribuindo-se maior importância às disciplinas propedêuticas, bem como a com a mudança na didática utilizada.

\section{Eixo Profissional}

O Direito, enquanto curso da área de ciências sociais aplicadas, tem o poder de transformar a realidade, facilitando a vida das pessoas, na medida em que atua na promoção da justiça, da verdade e da equidade. Nesse sentido, o objetivo do curso de Direito consiste em desenvolver no aluno a consciência de seu papel social, munindo-lhe do conhecimento necessário para assim proceder.

Nesse sentido, diante de conteúdos excessivamente extensos e de uma cultura jurídica segundo a qual o ensino do direito deve recair sobre a norma, acaba havendo "nos currículos, predominância do estudo do direito positivo e, em especial, o direito estatal, centrados nas teorias da soberania" (SILVA; FREITAS FILHO, 2012, p. 202).

Assim, ainda nitidamente influenciados pela cultura do positivismo jurídico, "muitos mestres ainda acreditam em dois pressupostos: a) o direito não precisa da interferência de outras disciplinas para ser explicado, pois "basta por si próprio"; e b) o aluno deve se ater ao estudo da legislação para ser um bom profissional". (ACHUTTI; OSÓRIO, 2014, p. 18).

Ademais, cumpre destacar que as características estruturais do ensino jurídico nas últimas duas décadas acentuam outro problema, qual seja: a distância entre a formação técnica e a formação crítica. Convivem em um mesmo espaço físico dois mundos completamente distintos, o dos professores dotados de formação instrumental e que se ocupam com a prática do direito e dos professores que de formação acadêmica que constituem minoria.

Segundo Frederico Augusto Barbosa da Silva e Roberto Freitas Filho (2012, p. 205), os docentes mais valorizados são aqueles dotados de um saber instrumental, os quais se constituem operadores técnicos, já os profissionais de perfil acadêmico, formados por um viés crítico, não são reconhecidos pelos alunos como pessoas de sucesso profissional, já que não ostentam os sinais de status atribuídos a profissões jurídicas.

Assim surge a perspectiva que os alunos esperam um curso jurídico instrumental, dogmático, informativo, na medida em que seus anseios profissionais, na maioria dos casos, se resumem a aprovação em concursos públicos, sejam concursos de carreiras jurídicas, sejam concursos de nível superior, por isso, as aulas 
expositivas, constituídas por monólogos infindáveis do professor, acompanhado de uma exposição técnica e acrítica seriam, teoricamente, as preferidas pelos alunos. Muitos estudantes veem na graduação uma espécie de "cursinho preparatório" para galgar aprovações em concurso.

Nesse sentido, Boaventura Santos (2004) menciona a ocorrência de uma crise institucional, segundo a qual as universidades não têm conseguido compatibilizar o oferecimento de uma formação humanística, exigida inclusive no Artigo $3^{\circ}$ da Portaria n ${ }^{\circ}$ 09/2004, com as exigências de produtividade do mercado.

A metodologia para o ensino das disciplinas profissionalizantes enfrenta, assim, um severo embate: de um lado temos uma minoria de docentes conscientes da importância da pesquisa para a formação completa e integral do Bacharel em Direito e de outro lado temos uma expressiva quantidade de alunos, cujo principal interesse é obter aprovação em concursos públicos, compostos por provas que selecionam "indivíduos capazes de memorizar informações e conceitos, mas não necessariamente aptos a aplicar os conceitos no momento decisório" (SILVA; FREITAS FILHO, 2012, p. 200).

Dessa forma, seguindo-se a lógica da lei de mercado da oferta e da procura, as instituições de ensino se adaptam aos pretensos interesses e expectativas dos alunos. Segundo Barbara Valentim Goulart e Debora Nitz Ferreira Elias (2010, p. 5301):

A transformação do ensino jurídico em mercadoria, considerando a necessidade de atendimento da demanda de alunos desprovidos de vocação e ao mesmo tempo interessados em assumir cargo público, fica demonstrada pela análise das grades curriculares, e verificando o grande número de disciplinas dogmáticas propostas, em contraposição ao número de disciplinas propedêuticas existentes. Assim, o Direito que se escolheu ensinar hoje é apenas o legalista, positivado na lei.

E é nesse cenário da constituição da educação como mercadoria, com matrizes curriculares eminentemente direcionadas ao ensino das disciplinas profissionalizantes, formação de profissionais técnicos, sem senso crítico, que atingimos o status de Universidades Mcdonalds:

A mercadoria oferecida deve ser produzida de forma rápida e de acordo com certas e "rigorosas" normas de controle da eficiência e da produtividade. $\mathrm{O}$ aluno, assim como o sanduíche, deve ser preparado de acordo com o protocolo. Sem boas bibliotecas, raciocínio, questionamentos ou qualquer pesquisa (a não ser a dos melhores preços e anseios do mercado). (WEBBER; HOHENDORFF, 2013, p. 5).

Conclui-se pela necessidade de alteração das metodologias utilizadas no ensino das disciplinas profissionalizantes, bem como nos seus objetivos, os quais devem ir além da mera preparação para aprovação em concursos públicos. Afinal, os instrumentos legislativos que regulamentam os currículos acadêmicos já preveem que o ensino jurídico deve formar profissionais humanos, com capacidade de análise, situação que não é alcançada em grande medida, pelas metodologias tradicionalmente implementadas pelos docentes. 


\section{Eixo prático}

Mediante a análise das matrizes curriculares, constata-se que as disciplinas com viés pratico apenas começam a surgir nos últimos semestres do curso de Direito. Dessa feita, o estudante de direito passa grande parte de sua formação acadêmica absorvendo passivamente inúmeras teorias para somente no fim do curso deparar-se com a prática profissional. Tércio Sampaio enfatiza que:

É preciso reconhecer que, nos dias atuais, quando se fala em Ciência do Direito, no sentido do estudo que se processa nas Faculdades de Direito, há uma tendência em identificá-la com um tipo de produção técnica, destinada apenas a atender às necessidades profissionais (o juiz, o advogado, o promotor) no desempenho imediato de suas funções. Na verdade, nos últimos cem anos, o jurista teórico, pela sua formação universitária, foi sendo conduzido a esse tipo de especialização fechada e formalista. (FERRAZJR, 1994, p. 49)

Dentre os currículos analisados, as disciplinas práticas do curso de direito ficam limitadas aos estágios supervisionados e aos escritórios de prática jurídica, os quais, em regra, são cursados no último ano de faculdade. Nesse sentido, Pedro Demo (2008, p. 45) afirma que os estágios, "são quase sempre caricaturais (..). Aparecem quase sempre no fim do curso. Transmitem logo a ideia errônea de que primeiro é mister mergulhar na teoria e somente depois pensar na prática”.

O perfil dos estudantes de direito, com suas aspirações profissionais direcionadas a realização de concurso público, aliada a mercantilização da educação, produz um quadro que resvala na insuficiência de disciplinas práticas no currículo dos cursos de direito. Conforme alerta Benedito Calheiros Bonfim:

O direito ministrado nos estabelecimentos de ensino é imobilista, e, por isso mesmo, resiste às mutações sociais e econômicas, com estas se conflitando. É evidente seu atraso em relação às ciências em geral e, em particular, às ciências sociais. O programa, os métodos, os manuais adotados nos cursos jurídicos pecam pelo teoricismo, ausência de espírito crítico e inadequação à realidade. Um sistema anacrônico, livresco, afastado do dinamismo da vida moderna, continua ser impingido aos alunos. A relação mestre/aluno, ainda não liberta do modelo antigo, conquanto apresente sinais de melhoria em algumas Faculdades, permanece formal, longe da interação desejada e necessária [...] (BONFIM, 1996, p. 81).

A baixa incidência de disciplinas práticas e a utilização de metodologias dogmáticas, meramente expositivas, refletem uma situação de atraso no ensino jurídico, afinal, compreender o direito não se limita a reproduzir suas leis. O direito é uma ciência social aplicada e deve, portanto, compreender a macro estrutura social em que se encontra inserido. Como afirma Paulo Freire (1996, p. 38), a prática docente crítica estimula a curiosidade epistemológica do sujeito, sendo esse o papel das disciplinas práticas.

Além da humanização do bacharel, as disciplinas práticas permitem a imersão da interdisciplinaridade no curso de direito, possibilitando a formação técnica ideal:

A formação técnica ideal constitui-se em três planos: o advogado precisa ter uma formação interdisciplinar e humanística, ressaltando a conexão estreita entre o Direito e outras áreas do conhecimento, como ciência política, sociologia, filosofia, lógica, retórica e semiologia, além de outras mais específicas, como biologia, energia nuclear e geologia, por exemplo. Assim, o bacharel tem oportunidade de obter uma base sólida sobre que assentar argumentação 
especificamente dogmática de sua atividade enquanto operador jurídico moderno. Além do aspecto técnico, porém, isto também deve permitir um aprimoramento na parte ética da profissão. (ADEODATO, 1997, p. 147).

A fusão da teoria com a prática não se limita a inserção de disciplinas práticas nas matrizes curriculares, tal objetivo poderá ser alcançado, de forma bem mais simples, com a utilização de algumas das várias técnicas de metodologias ativas em todas as demais disciplinas da matriz curricular, incluindo-se as de cunho propedêutico. Como expõe Paulo Freire, "por que não aproveitar a experiência que têm os alunos de viver em áreas da cidade descuidadas pelo poder público para discutir, por exemplo, a poluição dos riachos e dos córregos e os baixos níveis de bem-estar das populações?” (FREIRE, 1996, p.30).

Destaca-se que interdisciplinaridade e a compreensão do fenômeno jurídico como um todo e não apenas como um conjunto de disciplinas estanques advém da postura de conferir maior aproximação da teoria com a prática, expondo o estudante a um contexto social maior. A “aula magistral” (MELO FILHO; 1977, p.38 40) por si só não consegue atingir esse objetivo.

As críticas à aula magistral e ao modelo de aula exclusivamente expositivo perduram desde a década de 1990 e não obstante as incontáveis críticas, esse modelo ainda constitui a principal prática docente. Segundo Julio Pinheiro Faro (2014, p. 154), a maioria das escolas e faculdades de direito ainda se prendem ao dogmatismo e essa tendência é seguida pelas bancas de concurso e por Exames de Ordem. O apego à literalidade dos códigos, distante da realidade, ainda perdura nos cursos jurídicos.

Assim, a inserção de metodologias que contribuam para a fusão da teoria com a prática é um necessidade vislumbrada não apenas pelos teóricos do ensino, mas também encontra-se prevista na própria Resolução n 09/2004 que regulamenta os currículos dos cursos de Direito.

Impende destacar que o em 2014, foi aprovado o novo Plano Nacional de Educação por meio da Lei ${ }^{\circ}$ 13.005/2014, o qual estabeleceu que no mínimo, 10\% (dez por cento) do total de créditos curriculares exigidos para a graduação seja integralizado mediante a participação em programas e projetos de extensão universitária. Evidenciando uma preocupação dos legisladores em ampliar a interface entre teoria e prática, situação que poderá ser alcançada por diferentes meios: alteração didático pedagógica do modelo de ensino, revalorização da extensão universitária, não confusão do currículo mínimo previsto na Resolução nº 09/2004 com o currículo pleno e a consequente inserção de disciplinas com teor prático, dentre outros mecanismos.

\section{Metodologias Ativas e mudança das estratégias didático-pedagógicas}

Conforme exposto anteriormente, mediante analise documental das matrizes curriculares de cursos de direito do Estado do Ceará e da literatura especializada no assunto, revela-se a pouca utilização das técnicas de metodologias ativas de ensino e aprendizagem na graduação, bem como evidencia-se o hermetismo dos 
currículos acadêmicos em que são ofertadas, basicamente, as disciplinas estatuídas nas diretrizes educacionais da resolução nº9/2004.

Nesse cenário de graves problemas do ensino jurídico, a maioria dos estudiosos do tema propõe uma reformulação nos currículos acadêmicos. Ocorre que a regulamentação dos currículos acadêmicos no território nacional já passou por inúmeras alterações e mesmo assim, as incongruências persistem. Conforme expõe Horácio Wanderley (1992, p. 104), a tendência nas proposições de modificações dos currículos é que essa seja empreendida pelo ente estatal, de cima para baixo, com alteração na regulamentação federal, "o que se pode afirmar, com base na experiência histórica, é que a pretensão de corrigir o ensino jurídico através da simples alteração do currículo do curso é falsa" (RODRIGUES, 1992, p. 104).

A simples inserção de matérias nas matrizes acadêmicas, sem uma mudança de mentalidade dos docentes, em nada contribuirá para a superação da crise do ensino jurídico. Afinal, de que adianta criar legislação obrigando às Instituições de Ensino a ampliarem a oferta de disciplinas propedêuticas se essas continuarem a ser lecionada de forma dogmática e apartada da realidade? E, pior, sem que os alunos tenham consciência de sua importância?

A prova cabal de tal afirmativa consiste no fato de que a Resolução n 9/2004, a qual permite a captura de elementos com potencial transformador do sistema dogmático do ensino jurídico, ao estabelecer em seu artigo $3^{\circ}$ que o projeto político-pedagógico deverá assegurar uma formação humanística, axiológica, com conhecimento técnico, mas também com conhecimento e valorização de fenômenos jurídicos e sociais, adotando uma postura reflexiva e de visão crítica (FARO, 2014, p. 182); com mais de doze anos de vigência, ainda não conseguiu ser faticamente implementada.

Nesse sentido, entende-se que uma possível solução seria uma alteração pedagógica e não simplesmente curricular, inserindo-se as metodologias ativas como principal método de ensino. E, afinal, o que seriam metodologias ativas? Para Celso da Cunha Bastos (2006) seria um "processo interativo de conhecimento, análise, estudos, pesquisas e decisões individuais ou coletivas, com a finalidade de encontrar soluções para um problema”. Nesse sentido, a utilização de metodologias ativas propõe uma modificação no papel tradicionalmente desempenhado por professores e alunos. Nessa perspectiva metodológica, o docente age enquanto facilitador, permitindo que o discente possa pesquisar, analisar e refletir subjetivamente o que fazer para atingir seus objetivos.

Álvaro de Mello Filho (1977, p.33) apresenta um quadro esquemático que define os passos que devem ser seguidos para uma melhoria significativa do ensino jurídico, qual seja: habituar o discente ao raciocínio jurídico; a valorização da consciência e mentalidade; debater para saber pensar e o olhar para o aluno. Esses "passos" podem ser facilmente alcançados com a utilização de metodologias ativas.

Ademais, a aula expositiva dentre, as metodologias de ensino, ainda é a mais utilizada, por ser a mais 
cômoda para os alunos, uma vez que não exige grande esforço por parte destes em estudar previamente, afinal, basta que assumam uma postura passiva, de receptor do conteúdo que está sendo transmitido, sendo sujeito passivo no processo, não sendo sequer instado a intervir, em regra. Além de ser o método de ensino menos oneroso para as universidades, permitindo que haja sala com 50 alunos ou mais.

Aliada a aula expositiva, a utilização de apostilas e apontamentos produzidos pelo professor, faz com que os alunos fujam cada vez mais dos livros. Nesse ponto torna-se relevante colacionar as reflexões de José Wilson Ferreira Sobrinho (2000, p. 76):

O curso de Direito é particularmente sensível à questão dos apontamentos feitos na sala de aula. Quase sempre os estudantes imaginam que é suficiente estudá-los para ganhar nota dez. O pior é que contam com o concurso de professores irresponsáveis que fazem questões safadas que, obviamente, permitem notas igualmente safadas. É praticamente impossível convencer os alunos da importância de ler livros. O vício das anotações bastante em si - ou coisa bem pior: as famosas apostilas que alguns ousam distribuir para os estudantes - é uma nota triste dentro das Faculdades de Direito que enxovalha as notas formais que adornam currículos também formais, sem valor real. Isso, entretanto, não serve como justificativa para varrer a aula expositiva do mapa docente.

Eduardo de Oliveira Leite (2005, p. 30), discorrendo sobre a aula expositiva nos cursos de Direito traz interessantes considerações:

O papel do aluno é o de receptor da informação, numa posição de total passividade. Nada há de estranhável no fato - neste sistema - de que em investigação realizada nos Estados Unidos, em 1973, ficou constatado que dois terços das perguntas realizadas pelos docentes requeriam para sua resposta um simples relembrar de informações recebidas e devidamente decoradas, enquanto apenas um terço das restantes exigia para sua resposta a realização de uma operação lógica.

Não se propõe a completa abolição da aula expositiva, afinal ela apresenta seu valor pedagógico. O que se recomenda é a reformulação das aulas expositivas, com a alteração dos papeis assumidos por aluno e professor, em que o docente passará a ser um facilitador da aprendizagem e o aluno será estimulado a pesquisar, a socorrer-se aos livros para encontrar as respostas dos casos formulados pelo professor, a preparar-se com a antecedência para a aula, uma vez que esse também participará da exposição do conteúdo por meio de debates socráticos e seminários.

É inegável que a substituição das aulas expositivas para que ocorra a implantação de algumas das técnicas de metodologias ativas requer um aumento dos custos pela Universidade com a contratação de mais professores e adequação da estrutura física com ampliação no número de turmas, existe, entretanto, a necessidade de entender que o aluno não está na academia apenas para assistir aula expositiva. Sobre o assunto, Roberto A.R. de Aguiar (2004, p.211) diz:

Como a mercadoria vendida por essas faculdades é a aula, não há qualquer preocupação com a pesquisa, nem mesmo aquela que possa propiciar a qualificação docente. $\mathrm{O}$ ensino nada mais é do que a releitura malfeita de textos e manuais, um metadiscurso ralo sobre o teor das normas jurídicas e uma repetição daquilo que os manuais comentam, não expressando qualquer conteúdo técnico ou científico, mas doutrinário, no pior sentido. 
Impende ressaltar que existem varias técnicas de ensino, em que o aluno é posicionado em uma situação de protagonista na produção do saber, que não demandam um aumento dos gastos pela Universidade para serem implantados, tais como: seminários, debates socráticos, exposição de um filme seguida de discussão, método do caso, substituição das avaliações tradicionais pela produção de artigos científicos, em que o professor orientará aos alunos na produção do trabalho, dentre outras.

Paulo Freire (1996, p.52) já defendia o uso das metodologias ativas na educação, asseverando que na educação de adultos, o que alavanca a aprendizagem é a superação de desafios, a resolução de problemas e a construção do conhecimento novo a partir dos já existentes e, principalmente, as experiências dos indivíduos.

Pedro Demo, em seu livro O Bom Docente (2008, p. 45) propõe uma estrutura curricular em que em todos os semestres letivos haveria uma aproximação da teoria com a prática, conduzindo o aluno a uma identificação com a vivência profissional desde os primeiros anos de graduação, podendo as metodologias ativas funcionarem como vetor de promoção da interface entre teoria e prática, vejamos:

Por isso, algumas idéias poderiam ser as seguintes no ordenamento curricular do curso: a) colocar um ou dois semestres tipicamente propedêuticos, para estabelecer a regra da pesquisa como ambiente da aprendizagem; estuda-se aí metodologia científica, métodos e técnicas de pesquisa, estatística e todas as instrumentações quantitativas e qualitativas, informática, e assim por diante, com o propósito de plantar as bases e procedimentos do saber pensar; este período deveria ser, mais ou menos, um "mundo de Sofia"; b) a seguir, incluir em todo semestre pelo menos uma disciplina que provenha da prática, realizando a pesquisa a partir da prática, e trazendo-a para a devida teorização; tomando o exemplo da pedagogia, pode-se estudar a partir da prática a referência legal dos sistemas educacionais, a questão da avaliação e da disciplina, a estrutura institucional e de funcionamento, a problemática da gestão, e assim por diante; c) ao fim do curso, reservar um ano para exercício profissional stricto sensu, ainda que curricular, durante o qual o aluno assume o desempenho profissional da maneira mais íntegra possível, embora sempre como parte do trajeto formativo, de tal sorte que, terminado o curso, possa inserir-se no mercado de modo natural; d) durante esse ano, elabora uma "monografia" para teorizar as bases do exercício profissional, significando a confluência entre a capacidade de formular e de intervir.

O ensino dogmático e legalista, distante da realidade não absorve mais o corpo docente. A utilização de novas estratégias é uma necessidade urgente. Uma boa forma de aprimorar o ensino jurídico é a implementação das metodologias ativas, na medida em que essas valorizam a carga informativa com a qual os alunos chegam aos bancos acadêmicos, discutindo a razão de ser destes fatos. (FREIRE, 1996, p. 30)

\section{ANÁLISE DO PERFIL DO ESTUDANTE DE DIREITO E A NECESSIDADE DE REESTRUTURAÇÃO CURRICULAR E DAS METODOLOGIAS DE ENSINO}

Com o fito de analisar o perfil do estudante de direito no estado do Ceará, realizou-se pesquisa de campo, cuja coleta de dados deu-se por meio de Surveye snowball. A referida pesquisa consistiu na aplicação de questionário composto por 10 (dez) perguntas: (Qual o seu semestre?; Com qual gênero você se identifica?; 
Dentre as opções a seguir, qual a prática metodológica mais comum em sua sala de aula?; Qual a sua motivação em realizar o curso de Direito?; Você acredita que a grade curricular do seu curso é adequada para que você atinja seus objetivos profissionais?; Você se sente preparado para o mercado de trabalho?; Você acredita que as metodologias utilizadas em sua sala de aula são as mais adequadas para sua preparação profissional?; Você acredita que a quantidade de disciplinas com viés prático em sua matriz curricular é?, Você sabe o que são metodologias ativas?; Que grau de importância você atribui disciplinas propedêuticas (filosofia, sociologia, psicologia jurídica, etc); Sua faculdade é pública ou privada?).

O referido questionário foi elaborado na plataforma Google Docs, cujo linkfoi disseminado por meio de redes sociais (Facebook. Email, Whatsaap, etc), perfazendo a coleta de dados de 114 (cento e quatorze) entrevistados. Impende destacar que tal pesquisa de campo manteve o completo sigilo dos respondentes, não correndo qualquer identificação desses.

A pesquisa foi direcionada à coleta de opiniões dos estudantes de Direito nas Faculdades e Universidades públicas e privadas do Estado do Ceará. Os questionamentos foram direcionados a alunos que estavam cursando a partir do $5^{\circ}$ semestre, ou seja, o público alvo foi composto por alunos que já apresentavam uma certa vivência do curso de Direito.

Como resultado coletado da pesquisa de campo aplicada, destaca-se, inicialmente, que a maioria dos estudantes, em uma escala de notas 1 a 5, em que 1 consiste na atribuição de pouca ou nenhuma importância das disciplinas propedêuticas e 5 constitui o reconhecimento máximo da relevância dessas disciplinas, a expressiva maioria dos alunos atribuiu nota 3 , ou seja, os estudantes, mesmo os que já passaram da metade do curso de direito, ainda não reconhecem adequadamente a importância e contribuição dessas matérias na formação acadêmica.

\section{Figura 1 - Qual o grau de importância que você atribui às disciplinas propedêuticas?}

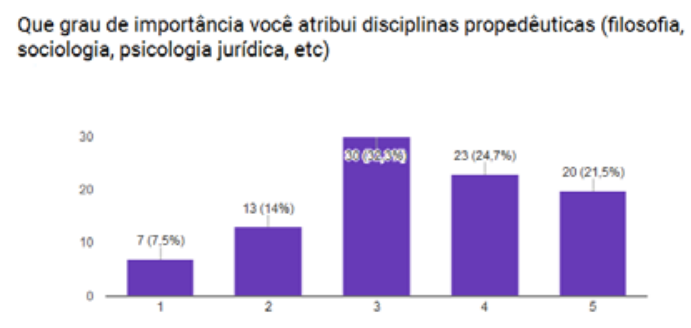

Tal constatação apenas reforça as considerações apresentadas no início do presente artigo, em que as faculdades, em regra, apenas ofertam as disciplinas previstas no eixo fundamental da resolução n 09/2004, fazendo do currículo mínimo, o currículo pleno, bem como a inadequação da técnica metodológica utilizada, uma vez que a aula meramente expositiva não é capaz de fazer com que aluno reconheça a importância das disciplinas 
propedêuticas, haja vista a dificuldade de estabelecer a relação dessas com o futuro profissional.

A pesquisa de campo refutou, entretanto, algumas concepções dos estudiosos do ensino jurídico. Não obstante a maioria dos alunos almeje a aprovação em concurso público, destaca-se que o interesse dos estudantes pela carreira de advocacia privada é bastante expressivo e nesse aspecto a inserção de disciplinas práticas e de metodologias ativas, em que os graduandos possam se deparar com problemas do quotidiano, são de extrema importância para que atinjam seus objetivos profissionais.

\section{Gráfico 2 - Qual a sua motivação em realizar o curso de direito?}

\section{Qual a sua motivação em realizar o curso de Direito}

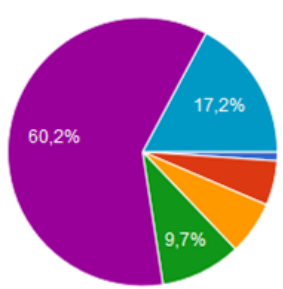

- Melhorar no próprio emprego

- Desenvolvimento pessoal

Seguir carreira acadêmica, com a ealização de Pós Graduaçã̃o,

Mestrado, Doutorado, etc

Prestar qualquer concurso de nivel

superior

Prestar concurso para carreiras

juridicas

- Advocacia privada

Conforme exposto anteriormente, alguns estudiosos do ensino jurídico, como Suelen da Silva Webber, Raquel Von Hohendorff (2013, p. 3), Renan Moreira de Norões Brito (2015, p. 168), dentre outros, afirmam que os alunos detêm preferencia por aulas expositivas dado seu principal objetivo profissional, aprovação em concursos públicos e o fato de não exigirem preparação previa.

A pesquisa empírica nos mostra, entretanto, que a suposta preferência dos alunos por aulas expositivas não subsiste, mesmo que esse tipo de metodologia seja mais cômoda ao alunado, eles detém a percepção de que tal forma de ensino não é a mais adequada para que atinjam seus objetivos profissionais ao término da faculdade, ou seja, os graduandos reconhecem a limitação de aulas exclusivamente expositivas seguidas de anotações de apontamentos e leitura de apostilas. 
Gráfico 3 - Dentre as opções a seguir, qual a prática metodológica mais comum em sua sala de aula?

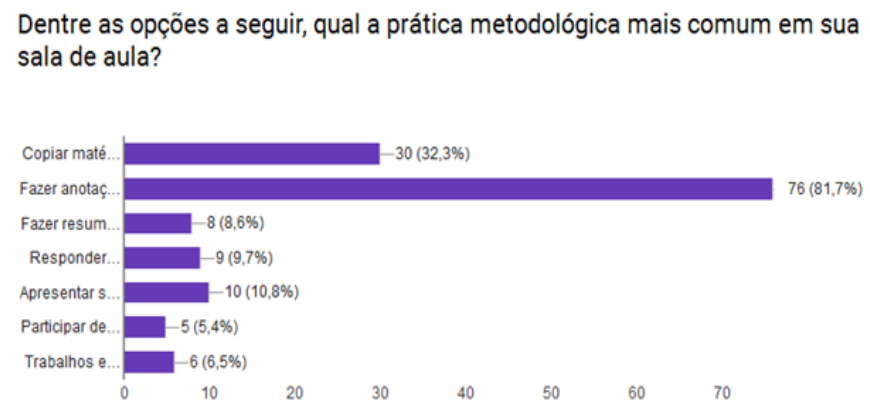

Gráfico 4 - Você acredita que as metodologias utilizadas em sua sala de aula são as mais adequadas para a sua preparação profissional?

\footnotetext{
Você acredita que as metodologias utilizadas em sua sala de aula são as mais adequadas para sua preparação profissional?
}

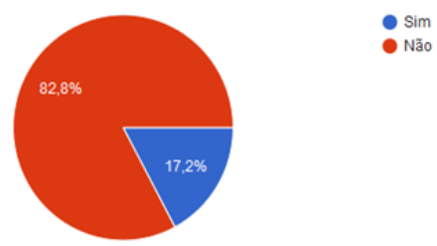

Ademais, mais de 70\% (setenta por cento) dos estudantes não se sentem preparados para o mercado de trabalho, ao passo que reconhecem a insuficiência na quantidade de disciplinas práticas ministradas ao longo do curso de direito.

Gráfico 5 - Você se sente preparado para o mercado de trabalho?

Você se sente preparado para o mercado de trabalho?

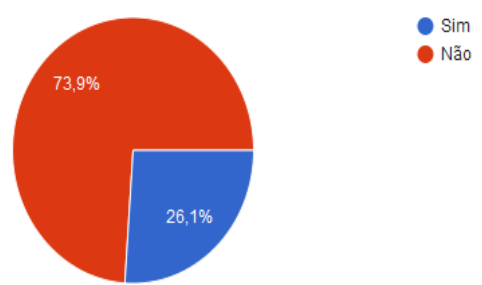




\section{Gráfico 6 - Quantidade de disciplinas com viés prático}

\section{Você acredita que a quantidade de disciplinas com viés prático em sua matriz curricular é}
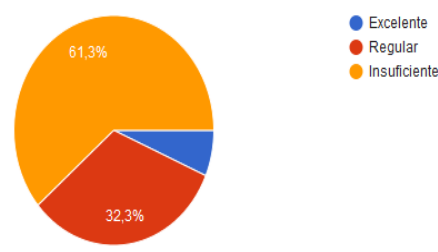

Insuficient

$\mathrm{Na}$ referida pesquisa, um dos questionamentos realizados foi se o entrevistado sabia o que são metodologias ativas, a expressiva maioria disse não saber do que se tratava esse tipo de prática.

\section{Gráfico 7 - Você sabe o que são metodologias ativas?}

Você sabe o que são metodologias ativas?

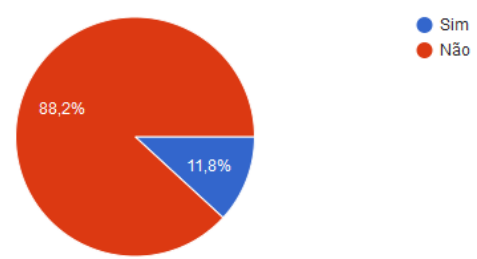

Tais evidências empíricas revelam que os professores não explicam aos alunos quais metodologias estão aplicando para a explanação do conteúdo e por qual motivo acreditam que o método utilizado seja mais adequado que outros disponíveis. Assim, o ensino jurídico ainda mantém os princípios de memorização e repetição utilizados na época dos jesuítas, abusando da explanação de conteúdos e de sua memorização, além de contrariar expressamente a Resolução n 09/2004, uma vez que essa dispõe em seu Artigo 9², parágrafo único, que os professores devem expor em seus planos de ensino, os quais devem ser entregues no início do semestre, as metodologias a serem utilizadas.

A expressiva maioria dos alunos que responderam a pesquisa, a qual viabilizou a realização do presente artigo, sentem-se despreparados para o mercado de trabalho e reconhecem que as metodologias predominantemente utilizadas em sala de aula não são as mais adequadas para a sua formação profissional, ou seja, os próprios alunos - os mesmos que demonstram um interesse expressivo na realização de concursos ao fim da faculdade - estão tecendo criticas ao modelo de aula expositiva. Um das possíveis causas da rejeição da aula exclusivamente expositiva é que em cada encontro são repassadas uma série de informações, descontextualizadas 
da vida real, não congregando o novo conhecimento com aquele que os alunos já dispõem, o que faz com que o estudante rapidamente esqueça o que foi transmitido nos semestres anteriores. Constata-se, portanto, que os alunos reconhecem a existência de falhas curriculares, mas, sobretudo, de insuficiências didático-pedagógicas.

\section{CONCLUSÃO}

O objetivo do presente estudo consistiu em caracterizar o perfil do estudante do curso de direito, e a partir de tal perfil, analisar a (in)adequabilidade dos currículos acadêmicos, propondo uma alteração didáticopedagógica do ensino jurídico, por meio da utilização das metodologias ativas.

Constatou-se que as faculdades e universidades públicas e privadas do Estado do Ceará, por meio de seus currículos acadêmicos, priorizam as disciplinas profissionalizantes em detrimentos das matérias propedêuticas e das disciplinas práticas, contribuindo para a formação de profissionais técnicos, acríticos e que se sentem despreparados para a atuação profissional.

A discussão em sala de aula sobre a relevância das disciplinas iniciais do curso de direito, como filosofia, sociologia, antropologia, psicologia jurídica, dentre outras, ainda deixa muito a desejar, uma vez que os alunos que já cursaram mais da metade do histórico acadêmico não conseguem compreender a extrema relevância dessas matérias em sua formação.

Muito dessa situação é decorrência da inadequação das metodologias utilizadas pelos professores, dissociando a teoria da prática e dificultando que os alunos estabeleçam a correlação da relevância das disciplinas propedêuticas com o seu futuro profissional e aliado a tal situação inclui-se a baixa oferta de disciplinas do eixo fundamental nos currículos.

Conforme foi demonstrado mediante gráficos construídos a partir dos dados coletados com a pesquisa empírica implementada, o estudante de direito ainda objetiva a aprovação em concursos, mas reconhece que a metodologia da aula expositiva não é suficiente para atingir a tal desiderato. Ademais, de forma expressiva, os alunos afirmaram pela insuficiência das disciplinas práticas nos currículos acadêmicos e consequente expressam o sentimento de despreparo para a atuação profissional.

Pelas considerações traçadas, conclui-se que o atual perfil do estudante de direito requer alteração urgente nas metodologias de ensino aplicada em sala de aula. Percebe-se que as regulamentações legislativas acerca dos currículos acadêmicos já avançaram bastante, mas não foi possível obter melhoras factíveis, circunstância que evidencia que a raiz do problema está na forma como os conteúdos são repassados, na didática implementada, afinal, de nada adiantará implementar mudanças curriculares se o modelo dogmático de ensino continuar a ser o predominante.

O receio de que, não ocorrendo necessariamente a "entrega" de conteúdos por meio das aulas 
expositivas, o aluno não tenha visão geral dos conteúdos, é infundado, primeiro, porque o conhecimento não é algo a ser adquirido, mas construído, e, segundo, porque agindo autonomamente, o aluno pode chegar à visão geral mais autêntica. "O mero armazenamento de conteúdos é uma velharia, porque todos se esvaem rapidamente no tempo, por força da marca disruptiva do conhecimento. Além de aprender conteúdos, é decisivo aprender a aprender" (DEMO, 2008, p. 41) e nesse aspecto a inserção de metodologias ativas na exposição de conteúdos é primordial.

O objetivo da graduação é a formação de um profissional completo, humano, ético e apto a atuar profissionalmente em qualquer área que desejar, por isso, o curso de graduação é tão diversificado e de longa duração. Nesse sentido, defende-se a implantação de metodologias ativas no ensino das disciplinas jurídicas. Conforme suscitado anteriormente, existem diversas técnicas de metodologias ativas que podem ser utilizadas sem impactar tão fortemente os orçamentos das faculdades e universidades.

Sem pretensões de esgotamento da temática analisada, o presente artigo propõe uma readequação da pedagogia tradicionalmente utilizada para a superação da grave crise que assola o ensino jurídico, fato que poderá ser seguido por uma reformulação dos currículos acadêmicos, para que esses sejam diversificados conforme as necessidades regionais, atendendo de fato às previsões da Resolução n 09/2004. Impende destacar, que a presente pesquisa apresenta limitações, uma vez que se restringiu a consultar opinião de alunos no Estado do Ceará, não analisando se tal realidade é mantida nos demais estado brasileiros, além de não ter se detido na discussão de qual das técnicas de metodologias ativas é mais adequada ao ensino jurídico e mais possível de ser prontamente aplicada, sem onerações substanciais às instituições de ensino superior. Para estudos posteriores, sugere-se ampliar a amostra para outras regiões do país.

\title{
LAW STUDENT PROFILE, USE OF ACTIVE METHODOLOGIES AND PEDAGOGICAL RESTRUCTURING OF ACADEMIC CURRICULA
}

\begin{abstract}
In an attempt to make the curriculum more flexible, resolution n ${ }^{\circ}$.09/2004 lays down the minimum content and extended the duration of the course. It is noted, however, that the aforementioned legislative instrument to hit your point, after all, both defenders, as critics of the curricular reforms, reach a common conclusion: the reforms did not solved the problem of legal education, since this remains far from reality. In this sense, this article aims to describe and analyze the law student profile, academic curricula and their suitability to reality, proposing a change of didactic-pedagogical legal education through the use of active methodologies. Bibliographical search was performed, and documentary. With regard to documentary research, analyzed curriculum matrices of law courses in Ceará, clarifying the relevance assigned to disciplines, vocational, practical and propedeutics. In addition, applied in the research an questionnaire, with quantitative approach, aiming to draw the profile of law students, identifying the main professional scopes and views of students about teaching methods and curriculum
\end{abstract}


organization. The development of the field work took place through the technique of Survey data collection and snowball. After checking the growing need for new forms of learning by the pupils as a result of the emergence of technologies, the conclusion was reached that, nevertheless, the relaxation of the curricular structure, formally established through resolution $n^{\circ}$. 09/2004, academic matrices are obsolete and are targets of criticism by the students. Thus, it is proposed, ad initio, a didactic-pedagogical education change, by applying active methodologies.

Keywords: Law Student; Active Methodologies; Academic Curriculum.

\section{REFERENCIAS}

ACHUTTI, Daniel; OSORIO, Fernanda. Por uma prática educativa criativa: alteridade e Transdisciplinaridade no ensino jurídico. 2014. Disponível em: < http:/ /www.facos.edu.br/>. Acesso em: 19 de novembro de 2016

ADEODATO, João Mauricio Leitão. Advogado em construção. Ensino Jurídico OAB 170 anos de cursos jurídicos no Brasil. Brasília: Conselho Federal da OAB, 1997.

AGUIAR, Roberto A.R. de. Habilidades: ensino jurídico e contemporaneidade. Rio de Janeiro: DP\&A, 2004.

BASTOS, C. C. Metodologias Ativas. Disponível em: <http://educacaoemedicina.blogspot.com.br/2006/02/metodologias-ativas.html>.Acesso em: 2 de novembro de 2016.

BITTENCOURT FILHO, José; ALMEIDA, Eneá de Stutz e. Onde estão as propedêuticas? Proposta pedagógica para compatibilizar a formação jurídica com o papel social dos operadores do Direito. 2003. Disponível em: <http://www.publicadireito.com.br/conpedi/manaus/arquivos/Anais/sao_paulo/2855.pdf>. Acesso em: 02.nov.2016.

BONFIM, Benedito Calheiros. OAB Ensino jurídico: diagnóstico, perspectivas e propostas. In: CONSELHO FEDERAL (Org.). OAB ensino jurídico: diagnóstico, perspectiva e propostas. 2.ed. Brasília, 1996.

BRASIL. Lei no 13.005, de 25 de junho de 2014. Aprova o Plano Nacional de Educação - PNE e dá outras providências. Disponível em: <https://www.planalto.gov.br/ccivil_03/_ato2011-2014/2014/lei/113005.htm>. Acesso em: 27 de novembro de 2016.

Resolução no 09, de 29 de setembro de 2004. Institui as Diretrizes Curriculares Nacionais de Graduação

em Direito e dá outras providências. Disponível em: <
http://portal.mec.gov.br/cne/arquivos/pdf/rces09_04.pdf>. Acesso em: 27 de novembro de 2016.

BRITO, Renan Moreira de Norões. A valorização excessiva da aula expositiva em detrimento de outras atividades acadêmicas no direito. XXIV Encontro Nacional do Conpedi - UFS, Florianópolis, 2015.

DEMO, Pedro. O bom docente. Fortaleza: Universidade de Fortaleza, 2008.

DEWES, João Osvaldo. Amostragem em Bola de Neve e Respondent-Driven Sampling: uma descrição dos métodos. 2013. 53 f. Monografia (Especialização) - Curso de Estatística, Universidade Federal do Rio Grande do Sul, Porto Alegre, 2013. 
DIAS, Renato Duro. Relações de poder e controle no currículo do curso de direito da FURG. Tese de doutorado. Programa de pós-graduação em educação. Pelotas: UFPEL, 2014.

FARO, Júlio Pinheiro. O habitus do ensino jurídico: Uma crítica a partir das perspectivas de Pierre Bourdieu e Jean-Claude Passeron e de Dermeval Saviani. Panóptica, Vitória, v. 9, n. 27, p.147-198, 2014.

FERRAZ JR., Tércio Sampaio. Introdução ao Estudo do Direito: técnica, decisão e dominação. 2. ed. São Paulo: Atlas, 1994.

FILHO, Álvaro. Metodologia do Ensino Jurídico. Fortaleza: Imprensa Universitária da Universidade Federal do Ceará, 1977.

FREIRE, Paulo. Pedagogia como autonomia: saberes necessários à prática educativa. 30. ed. São Paulo: Paz e terra, 1996.

FREITAS, Henrique et al. O método de pesquisa Survey. Revista de Administração, São Paulo, v. 35, p.105-112, jul. 2000.

GOULART, Barbara Valentim; ELIAS, Debora Nitz Ferreira. Ausência de vocação e as "necessárias" adaptações mercadológicas: A derrocada do ensino jurídico. XIX Conselho Nacional de Pesquisa e Pós-Graduação em Direito: CONPEDI, Fortaleza. 2010.

LEITE, Eduardo de Oliveira. A Aula em Direito. In: Getulino do Espírito Santo Maciel; João Bosco da Encarnação (Org.). Seis Temas Sobre o Ensino Jurídico. São Paulo: Cabral, 2005.

MACHADO, Antônio. Ensino Jurídico e Mudança Social. São Paulo: Atlas, 2009.

PAVIANI,J. e POZENATO,J. C. A Universidade em debate. Caxias do Sul: EDUCS, 1980.

ROCHA, Salete Casali; ALVES, Roseli Teresinha Michaloski; MUJAHED, Daniela Urio. O ensino jurídico e a pedagogia histórico crítica. In: LEITE, Maria Cecília Lorea; VAN-D ðNEM, José Octavio; HENNING, Ana Clara Correa. Contemporâneidade, imagens da justiça e ensino jurídico. São Leolpodo: Casa Leiria, 2016.

RODRIGUES, Horácio Wanderley. A crise do ensino jurídico de graduação no Brasil contemporâneo: Indo além do senso comum. 1992. 417 f. Tese (Doutorado) - Curso de Direito, Ciência Jurídicas, Universidade Federal de Santa Catarina, Florianópolis, 1992.

SILVA, Frederico Augusto Barbosa da; FREITAS FILHO, Roberto. Ensino Superior do direito, concurso e a monografia jurídica. In: LIMA, Gretha Leite Maia Correia; TEIXEIRA, Zaneir Gonçalves. Ensino Jurídico: Os desafios da compreensão do direito: Estudo em homenagem aos 10 anos do curso de direito da Faculdade Christus. Fortaleza: Faculdade Christus, 2012.

SOBRINHO, José Wilson Ferreira. Didática e Aula em Direito. Porto Alegre: Sergio Antônio Fabris Editor, 2000.

WEBBER, Suelen da Silva; VON HOHENDORFF, Raquel. Ensino Jurídico em Terrae Brasilis: reflexões a partir das lições Waratianas do Senso Comum Teórico dos Juristas. XXII Conselho Nacional de Pesquisa e Pós Graduação em Direito: CONPEDI, São Paulo, 2013. 
Quaestio Iuris

Trabalho enviado em 18 de agosto de 2017. Aceito em 09 de novembro de 2017. vol. 11, n. 02, Rio de Janeiro, 2018. pp. 817 - 838 DOI: $10.12957 /$ rqi.2018.29655 